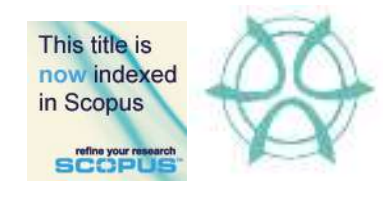

PLANNING MALAYSIA:

Journal of the Malaysian Institute of Planners

SPECIAL ISSUE V (2016), Page 145 - 156

\title{
PREFERENCES OF STUDENT RESIDENTS TOWARDS SUSTAINABILITY WITH THE CONCEPT OF BIOCLIMATIC DESIGN
}

\author{
Adi Ainurzaman Jamaludin ${ }^{1}$, Hazreena Hussein ${ }^{2}$, Nila Keumala ${ }^{3}$ \& Ati Rosemary \\ Mohd Ariffin ${ }^{4}$ \\ ${ }^{1}$ Institute of Biological Sciences \\ Faculty of Science \\ UNIVERSITI OF MALAYA
}

${ }^{2}$ Centre for Sustainable Urban Planning \& Real Estate

${ }^{3,4}$ Centre for Building, Construction \& Tropical Architecture

Faculty of Built Environment

UNIVERSITI OF MALAYA

\begin{abstract}
A satisfaction and perception survey was carried out at a residential college building in Kuala Lumpur. It was acknowledged as an energy efficient building due to the most considerate implementation of bioclimatic design concept. Currently, there is no specific preference studies were done in this type of building in the equatorial climate region. 266 respondents were received, relying on $95 \%$ confidence level and $\pm 5 \%$ margin of error from the overall population. The satisfaction and perception levels of residents are found to be positive with the concept of bioclimatic design. A majority of them are at a comfort level in all performance indicators including the internal courtyard, thermal comfort and indoor air quality, day lighting and landscape features, which contributed to the increased work productivity. Indirectly, it shows that the bioclimatic design concept at an old residential building is still appropriate to meet the needs of contemporary life while increasing the efficiency of electricity usage. Nevertheless, the positions of the rooms should be highly considered in implementing the improvement measures for increasing the comfort level of the room when this aspect, rather than the gender aspect, considerably influences the satisfaction and perception levels of respondents.
\end{abstract}

Keyword: Bioclimatic design, internal courtyard, post occupancy evaluation, residential, sustainable. 
Adi Ainurzaman Jamaludin, Hazreena Hussein, Nila Keumala, Ati Rosemary Mohd Ariffin

Preference of Student Residents Towards Sustainable - Energy Efficient Building with Bioclimatic Design Strategies

\section{INTRODUCTION}

Sustainable development has led to a number of concept and approaches to designing buildings that assist in reducing pollution and resource consumption (Hyde, 2008). In 1960s, a new concept of bioclimatic design was introduced as a process of design to ensure favourable microclimatic conditions for human comfort by considering the disciplines of human physiology, climatology and building physics (Olgyay, 1963; Bondars, 2013). This concept is using natural energy sources and sinks; without the use of any electromechanical devices or systems (Yeang, 2008; Hyde, 2000). Thus, it able to reduce the operating costs, enhance building marketability, reduce potential liability from indoor air quality problems and increase occupants' performance and productivity (Tiyok, 2009). In the long term, encourage sustainable development in the built environment by helping alleviate the problems concerning the depletion of energy resources and the deterioration of the environment ( $\mathrm{Li}$ et al., 2013).

The effectiveness of bioclimatic design concept in providing comfortable living space can be evaluated by using the Post-Occupancy Evaluation (PoE) (Jamaludin et al., 2014a; Amole, 2009). PoE is defined as the process of evaluating buildings in a systematic and rigorous manner after they have been built and occupied for some time to understand the mutual interactions between the building and users' needs (Preiser, 1995). The PoE integrates the occupants' behaviours, perceptions and opinions, and outlines the issues which will then be monitored (Khalil et al., 2008).

The PoE is widely acknowledged but rarely practiced as there is a lack of agreed-upon protocol, measures and procedures which make comparison difficult (Meir et al., 2009). The implementation of PoE is frustrated by ownership, liability, lack of knowledge and lack of progress (Hadjri \& Crozier, 2009). Additionally, the culture was also highlighted as a barrier to the PoE process when the occupants may feel that moving into a new working environment is disruptive enough (Riley et al., 2010). In Malaysia, the term PoE is still new while the aspects of evaluating building performance are not widely emphasised (Zakaria \& Hamzah, 2007). There are no systematically collected data for various types of building in Malaysia and most of the studies done previously tend to focus on office buildings (Khalil \& Nawawi, 2008; Khalil \& Husin, 2009). In other words, there are no specific studies were done on the residential building with the bioclimatic design concept in the equatorial climate region.

The aim of this study is to analyse the residents' satisfactions and perceptions of an old residential college focusing on four performance indicators. There are elements of internal courtyard, thermal comfort and indoor air quality, day lighting and landscape, with regard to gender, race and ethnicity, as well as the location of the room according to the floor levels. This residential building is acknowledged as a residential college building with the efficient use of electricity due to the best implementation of bioclimatic design concept, particularly day 
PLANNING MALAYSIA

Sustainable Urban Development

lighting and natural ventilation (Jamaludin et al., 2013). Unfortunately, the efficient use of electricity is not the ultimate victory of the building design when the occupants are suffering with uncomfortable indoor surroundings, especially in terms of thermal comfort and visual comfort (Jamaludin, 2014). Therefore, the effects of the recent adoption of bioclimatic design concept in influencing the residents' comfort levels and the appropriateness of an old building to meet the needs of contemporary life will be revealed subjectively through this PoE. Indirectly, this will contribute to the establishment of PoE standard methods and pragmatic models for multi-residential buildings in Malaysia. Additionally, it will produce a set of results which is easy to compare with other studies in the future in order to provide indications of improvement towards sustainable transformation.

\section{RESEARCH DESIGN AND APPROACHES}

\section{Building Description}

The residential college building is a multi-residential building, which provides accommodation for university students. This building is also referred as a hostel that contains leisure areas, lounges, meeting rooms and laundry facilities. Dayasari Residential College (Dayasari RC) established in 1966 with $18,212.51 \mathrm{~m}^{2}$ of total floor area. This residential college is low-rise, naturally ventilated building and able to accommodate 847 residents at one time. The location of this residential college is $3^{\circ} 07^{\prime} 39.0^{\prime \prime} \mathrm{N}, 101^{\circ} 39^{\prime} 30.1^{\prime \prime} \mathrm{E}$ and showed in Figure 1. 


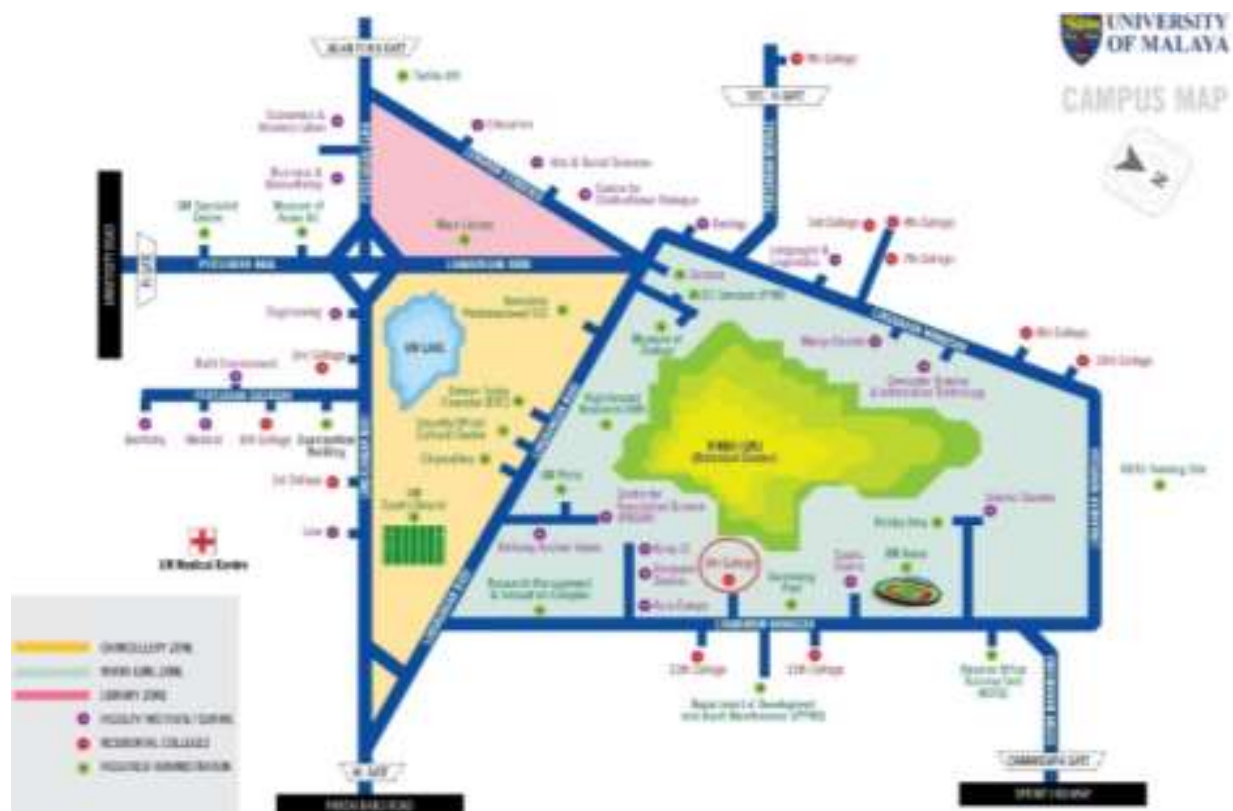

Figure 1: The location of Dayasari RC in UM campus (University of Malaya, 2015).

The building arrangement is based on the internal courtyard arrangement that encourages various implementations of bioclimatic design concept, especially under the day lighting and natural ventilation conditions (Jamaludin et al., 2011). The typical room's floor area and volume are $16.35 \mathrm{~m}^{2}$ and $45.78 \mathrm{~m}^{3}$, respectively. A typical elevation and floor plan of Dayasari $\mathrm{RC}$ is presented in Figure 2. 


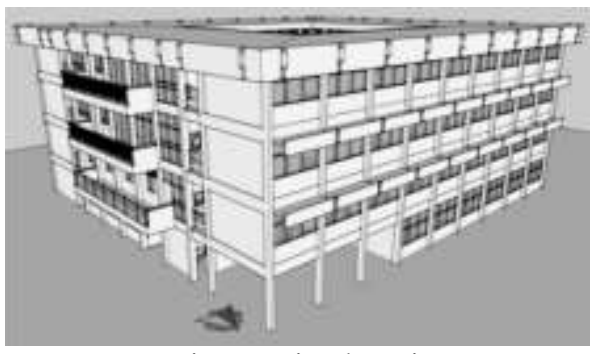

Front isometric elevation

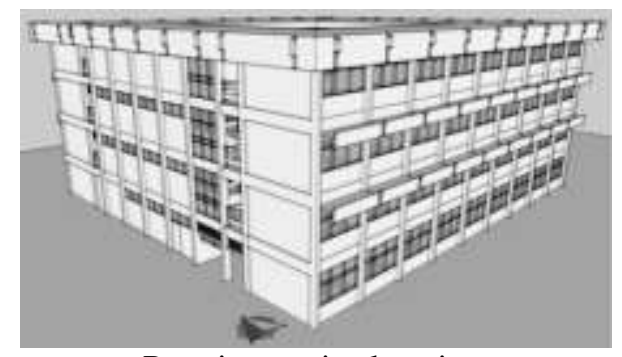

Rear isometric elevation
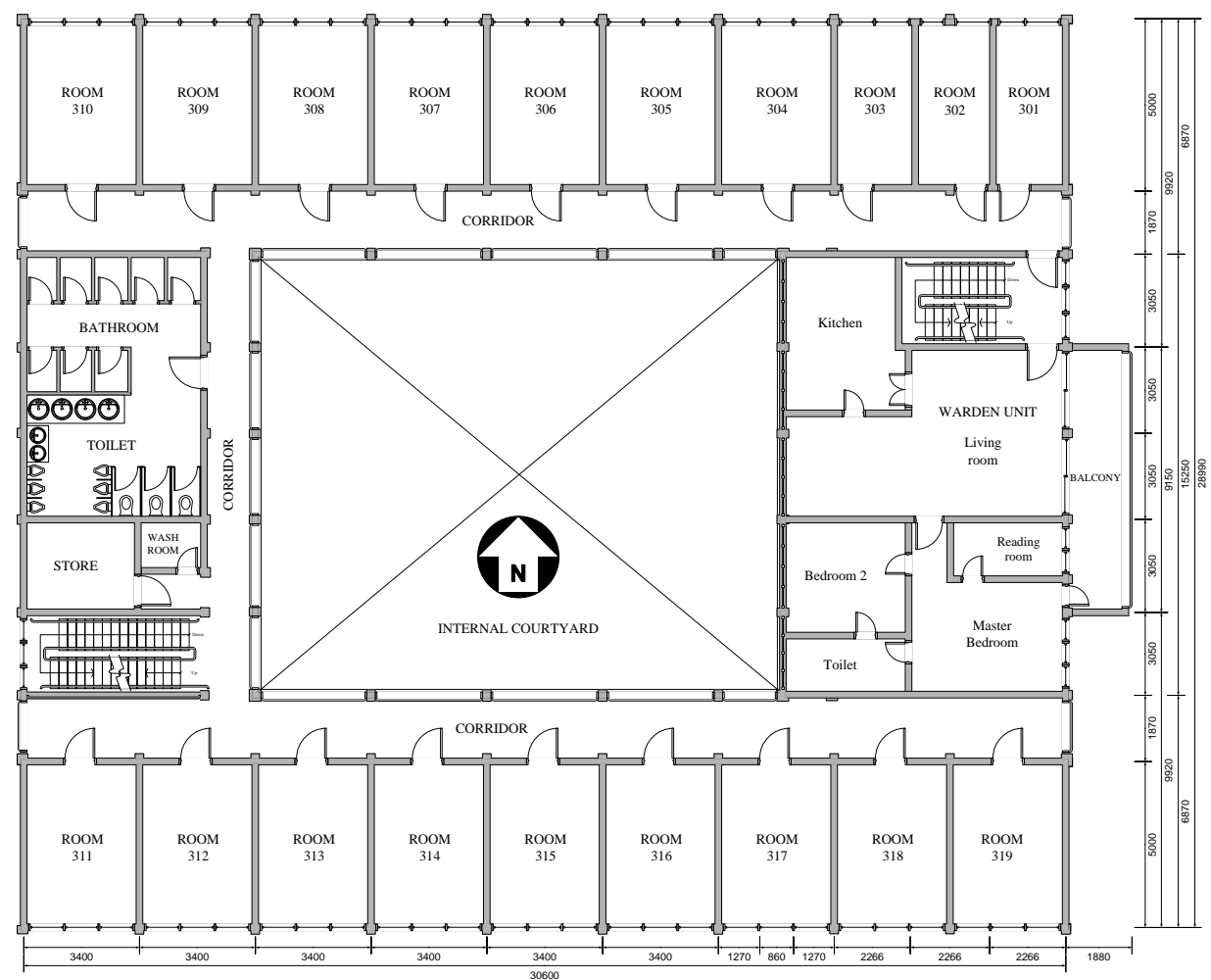

Floor plan

Figure 2: Typical elevation and floor plan of the Dayasari RC building.

The building's orientation to the sun path is north-south that reduces the glare and the thermal effects inside the rooms. At the East-west orientation, there are only service areas, such as toilets, bathrooms, stores, staircases and balconies. The internal courtyard provides daylight and natural air in the corridor and staircase area whereas inside the room daylight and natural air can be obtained through the transom on top of the entrance door and the wall. Thus, lessening the 
Adi Ainurzaman Jamaludin, Hazreena Hussein, Nila Keumala, Ati Rosemary Mohd Ariffin

Preference of Student Residents Towards Sustainable - Energy Efficient Building with Bioclimatic Design Strategies

usage of the corridor lamp during daytime is difficult to achieve at other residential college buildings with a linear arrangement of building layout (Jamaludin et al., 2012). Consequently, Dayasari RC has among the lowest Energy Efficiency Index $\left(34.52 \mathrm{kWh} / \mathrm{m}^{2} /\right.$ year $)$ compared to the other residential colleges; which are in the range of 40 to $125 \mathrm{kWh} / \mathrm{m}^{2} /$ year (Jamaludin et al., 2013).

Dayasari RC was designed with glare protection and adjustable/fixed opening options. There are two types of windows with tinted glasses, centre pivot and awning. The window to wall ratio (WWR) is quite big, 0.66 , while the window area is $6.41 \mathrm{~m}^{2}$. Subsequently, the operable window area is only $4.20 \mathrm{~m}^{2}$ with 0.43 of operable WWR. The combination of operable window and transom on top of the entrance door and the wall forms cross-flow/two-sided ventilation, which encourages natural ventilation inside the room. In order to produce significant shadow effects to the rooms, there are large horizontal overhangs along the window in each room. These features are not available in the rooms on the ground floors. As located next to UM Rimba Ilmu Botanical Garden, this residential college is surrounded by a highly vegetated area with high plant diversity (Jamaludin et al., 2014b). Most of the plants are well matured with huge canopies that are capable of covering the ground. The plant composition also shields the building from maximum sunlight penetration especially in the midafternoon (Jamaludin et al., 2012; Al-Obaidi \& Woods, 2006).

\section{Post Occupancy Evaluation}

The study by Jamaludin et al. (2014a) on satisfactions and perceptions of residents towards bioclimatic design concept at residential college building has been adapted to restructure the questionnaires. The questionnaires have been improved with the addition of several performance indicators. A number of questions were also added to obtain a clearer picture of their satisfaction, perception level of the residents and also the acceptance level towards the implemented bioclimatic design concepts.

The questionnaires use a Likert Scale format where each number generally responds to a specific scale as listed in below,

- -2 : very poor/not at all/very uncomfortable/much decreased/too dark/ very dissatisfied,

- -1: poor/slightly/uncomfortable/decreased/dark/dissatisfied,

- 0: fair/moderate/neither/no changes,

- +1: good/very/comfortable/increased/bright/satisfied,

- +2: very good/extremely/very comfortable/much increased/too bright/ very satisfied.

For thermal comfort, ASHRAE 7 point of the thermal sensation scale has been adopted in the questionnaires (Singh et al., 2011). The scale ranges from -3 
to +3 where, -3 : cold, -2 : cool, -1 : slightly cool, 0 : neutral, +1 : slightly warm, +2 : warm, and +3 : hot.

To understand the living behaviour of residents for sustaining the comfort level of their room, a further survey was done by focusing on the usage pattern of the windows and ceiling fan. The questionnaires were distributed to all residents with the minimum number of feedbacks and with reliance on $95 \%$ of the confident level and $\pm 5 \%$ margin of error from the overall population at each residential college. A simplified formula introduced by Yamane (1967) was used to calculate the sample sizes,

$$
\mathrm{n}=\mathrm{N} / 1+\mathrm{N}(\mathrm{e})^{2}
$$

where, $\mathrm{n}$ is sample size, $\mathrm{N}$ is the population size and $\mathrm{e}$ is the level of precision. In this study, the level of precision is 0.05 .

The survey was carried out just before the academic session ended and the long semester break was about to begin. Thus, the results obtained were more accurate as residents have stayed for at least one semester or 14 weeks at the residential college.

There are no changing seasons, which would have significantly affected the result of the survey because Kuala Lumpur has a constant annual average of temperature and humidity, $26.7^{\circ} \mathrm{C}$ and $83 \%$ respectively (Ahmad, 2008). Kuala Lumpur is only affected by the northeast monsoon from October to March which brings more rainfall (Malaysian Meteorological Department, 2015).

The statistical analyses that include the descriptive analysis were done by using statistical computer software package. The analysis was extended by way of comparing the percentage of respondents with regard to gender, as well as the location of the room according to the floor levels.

\section{RESULTS AND DISCUSSION}

The results of the satisfaction and perception survey of residents at Dayasari RC are presented in Table 1.

Table 1: The result of satisfaction and perception survey

\begin{tabular}{llccccc}
\hline & & & \multicolumn{4}{c}{ Likert scale / } \\
The performance indicators & \multicolumn{4}{c}{ Residents' responses (\%) } \\
\cline { 3 - 7 } & & $\mathbf{- 2}$ & $\mathbf{- 1}$ & $\mathbf{0}$ & $\mathbf{+ 1}$ & $\mathbf{+ 2}$ \\
\hline Internal & 1.The general room layout & 1.5 & 7.5 & 27.2 & 50.2 & 13.6 \\
courtyard & 2.The residential building layout & 0.4 & 8.7 & 28.7 & 50.2 & 12.1 \\
& 3.The adequacy of room in fulfil the needs & 1.1 & 11.4 & 25.5 & 49.8 & 12.2 \\
& 4.The overall quality of the residential building & 1.1 & 6.0 & 28.7 & 52.1 & 12.1 \\
& 5.The overall comfort level of the room & 0.8 & 4.5 & 29.1 & 53.6 & 12.1 \\
& 6.The influence of overall room conditions on the & 0.8 & 4.5 & 26.8 & 49.4 & 18.5 \\
& degree of work productivity & & & & & \\
& 7.The thermal comfort of the room & 3.4 & 11.7 & 29.7 & 43.6 & 11.7
\end{tabular}


Adi Ainurzaman Jamaludin, Hazreena Hussein, Nila Keumala, Ati Rosemary Mohd Ariffin

Preference of Student Residents Towards Sustainable - Energy Efficient Building with Bioclimatic Design Strategies

\begin{tabular}{lllllll}
\hline Thermal & 8.The ventilation \& indoor air quality of the room & 1.9 & 13.4 & 29.8 & 46.2 & 8.8 \\
$\begin{array}{l}\text { comfort } \\
\text { and indoor } \\
\text { air quality }\end{array}$ & 9.The ventilation control in the room & 1.1 & 14.2 & 37.5 & 39.8 & 7.3 \\
\hline Day & & 3.1 & 17.6 & 39.3 & 31.7 & 8.4 \\
lighting & 11.The adequacy of day lighting in the room & 4.2 & 12.0 & 34.4 & 40.9 & 8.5 \\
& 12.The day lighting control in the room & 1.5 & 9.5 & 37.4 & 42.4 & 9.2 \\
& 13.The overall quality of day lighting in the room & 1.5 & 7.7 & 28.8 & 48.5 & 13.5 \\
& 14.The view out of the room from the inside & 0.4 & 11.1 & 30.3 & 39.8 & 18.4 \\
& 15.The windows/opening area of the room & 0.4 & 8.0 & 30.5 & 45.8 & 15.3 \\
\hline Landscape & 16.The landscape quality at Dayasari RC areas & 1.5 & 8.0 & 33.7 & 48.7 & 8.0 \\
features & 17.The landscape quality in the internal courtyard & 1.5 & 6.1 & 35.9 & 48.9 & 7.6 \\
& 18.The influence of landscape on the quality life & 0.8 & 7.3 & 30.2 & 47.7 & 14.1 \\
\hline
\end{tabular}

According to the percentages, the majority of respondents were experiencing a satisfactory level of comfort in all performance indicators, except for the provision of air movement under the thermal comfort and indoor air quality elements. About $50.2 \%$ of respondents claimed that the general room and residential building layout which is the internal courtyard with open corridor were 'good'. Meanwhile, $49.8 \%$ agreed that the rooms 'had fulfilled their needs very much. The majority of the residents, which were represented by $52.1 \%$ felt 'good' about the overall quality of the residential building and $53.6 \%$ of them were 'comfortable' with the overall condition of the room. Consequently, $49.4 \%$ claimed that the degree of work productivity had 'increased' considerably.

Under the thermal comfort and indoor air quality elements, the majority of respondents felt 'good' with all indicators, which are the thermal comfort in the room $(43.6 \%)$ and the ventilation and air quality in the room (46.2\%). A smaller number of people or only around $39.8 \%$ had given good words about the control of the ventilation in the room. For the provision of air movement in the room, about $39.3 \%$ representing the majority voted for 'neither'. Hence, we noted that $59.7 \%$ of respondents were highly reliant on the ceiling fan at the highest speed of five $(50.2 \%)$, rather than natural ventilation through the opening of windows in order to promote air circulation and movement inside the room, as presented in Table 2.

Further survey on the usage pattern of windows and ceiling fans at Dayasari RC revealed that the 'monkey' (38\%) became the main reason for the residents to not open the windows, which was then followed by 'privacy' (20.5\%), 'safety' (16.1\%), 'dust' (9.8\%), 'rain' (6.3\%), 'others' $(5.9 \%)$ and 'insect' (3.4\%). However, some of the residents are still keeping the windows 'frequently' open (30.4\%) especially in the 'morning' (27.6\%). Comparatively, the insects were the main reason why residents did not open the windows of residential buildings in the hot-humid climate of Malaysia (Kubota et al., 2009).

Regarding the day lighting aspects, the majority of respondents $(48.5 \%)$ were 'satisfied' with the overall quality of day lighting in the room. They claimed that the adequacy of day lighting in the room was 'bright' (40.9\%) with a 'good' 
PLANNING MALAYSIA

Sustainable Urban Development

control (42.4\%). The existing windows/opening area of the room was 'good' (45.8\%) which was indirectly able to give a 'good' view (39.8\%) out of the room from the inside.

Table 2: The usage pattern of windows and ceiling fan

\begin{tabular}{|c|c|c|c|c|c|}
\hline \multirow{3}{*}{$\begin{array}{l}\text { The frequency of ceiling } \\
\text { fan usage in a day }\end{array}$} & \multicolumn{5}{|c|}{ Residents' responses (\%) } \\
\hline & Never & Rarely & Sometimes & Frequently & $\begin{array}{l}\text { Every } \\
\text { time }\end{array}$ \\
\hline & 0.4 & 3.1 & 10.9 & 26.0 & 59.7 \\
\hline \multirow{2}{*}{$\begin{array}{l}\text { The fan speed is often } \\
\text { used }\end{array}$} & One & Two & Three & Four & Five \\
\hline & 0.4 & 2.7 & 17.1 & 29.6 & 50.2 \\
\hline \multirow{2}{*}{$\begin{array}{l}\text { The frequency of the } \\
\text { windows is kept open in } \\
\text { a day }\end{array}$} & Never & Rarely & Sometimes & Frequently & $\begin{array}{l}\text { Every } \\
\text { time }\end{array}$ \\
\hline & 18.3 & 14.8 & 21.0 & 30.4 & 15.6 \\
\hline \multirow{2}{*}{$\begin{array}{l}\text { The time of windows } \\
\text { has been always open in } \\
\text { a day }\end{array}$} & Never & Morning & Afternoon & Evening & Night \\
\hline & 25.4 & 27.6 & 16.8 & 19.0 & 11.2 \\
\hline \multirow{2}{*}{$\begin{array}{l}\text { The reason for not } \\
\text { opening the windows }\end{array}$} & Safety & Rain & Dust & Monkey & Others \\
\hline & 16.1 & 6.3 & 9.8 & 38.0 & 5.9 \\
\hline
\end{tabular}

The quality of landscape setting at both residential college area and the internal courtyard area was 'good' with $48.7 \%$ and $48.9 \%$ of total respondents, respectively. About $47.7 \%$ of respondents claimed that the landscape setting in both areas was 'very' influential to the life quality. The advantage of the internal courtyard in promoting day lighting and natural ventilation would not be denied as the presence of a landscape with green trees provides better environment than the open sky (Monteiro \& Alucci, 2009) and they improve the room and building conditions even when receiving direct heat radiation and penetration from the worst orientations for the equatorial region; east and west (Jughans, 2008). The tree canopies have significant filtration capabilities which contribute to the reduction of terrestrial radiation, cooling the ground surfaces by capturing more latent heat, reducing air temperature by promoting more evapotranspiration, and effectively improve the outdoor thermal comfort, especially in open spaces of the tropical climate region (Shahidan et al., 2010). It also indirectly affects the indoor temperature and the cooling load of the building through shading and insulation effects (Yeang, 2008). Moreover, the vegetation-integrated buildings are more liked, aesthetically pleasing, and restorative than the houses without vegetation (White \& Gatersleben, 2011).

Regarding thermal comfort elements, a detailed survey has been done by adopting thermal sensation votes on ASHRAE 7 point sensation scale, which ranges from -3 to +3 . The majority of the respondents, $39.3 \%$ claimed to have been feeling 'neutral', as presented in Table 3 . 
Adi Ainurzaman Jamaludin, Hazreena Hussein, Nila Keumala, Ati Rosemary Mohd Ariffin

Preference of Student Residents Towards Sustainable - Energy Efficient Building with Bioclimatic Design Strategies

Table 3: Thermal sensation votes

\begin{tabular}{ccccccc}
\hline \multicolumn{7}{c}{ ASHRAE 7 point sensation scale / Residents' responses (\%) } \\
\hline-3 & -2 & -1 & 0 & +1 & +2 & +3 \\
Cold & Cool & Slightly cool & Neutral & Slightly warm & Warm & Hot \\
0.4 & 7.0 & 8.7 & 39.3 & 25.2 & 16.5 & 2.9 \\
\hline
\end{tabular}

Further statistical analysis was done by comparing the percentage of respondents with regard to gender. There were not many different responses between genders when comparing all elements simultaneously, except for their responses on the landscape elements. The majority of female respondents rated the internal courtyard as 'very' influential on their quality of life, while the male rated it as 'moderate'. This is in the line with Karjalainen (2007) and Parsons (2002), who claimed that the differences in the responses of male and female; especially in terms of thermal comfort, were generally small.

\section{CONCLUSIONS}

The majority of the respondents are at a comfort level in all performance indicators of internal courtyard, thermal comfort and indoor air quality, day lighting and landscape features, which indirectly increase the degree of work productivity. Therefore, the bioclimatic design concept at an old residential building is still appropriate to meet the needs of contemporary life. Furthermore, the concept can increase the efficiency of electricity usage without suffering the occupants with uncomfortable indoor surroundings, especially concerning thermal comfort and visual comfort. However, there is still room for improvement, especially on the provision of air movement in the room when the majority of the residents rated one notch lower as compared to the other indicators.

The location of the room, rather than the gender aspect considerably influences the satisfaction and the perception level of respondents. Different responses gave by the residents according to the floor levels. These aspects should be highly considered in implementing the improvement measures to ensure the comfort standards of the room towards sustainable transformation, especially in urban area. The internal courtyard should be fully optimised while trees in the landscape; either in the internal courtyard or surrounding residential buildings, must appropriately be designed to meet sufficient daylight and ventilation requirements.

In future research, it is necessary to combine both subjective and objective evaluations through field measurement with specific equipment to have an accurate result in the survey. The combination of these assessments will be able to provide more comprehensive results for the issues investigated. 
PLANNING MALAYSIA

Sustainable Urban Development

\section{ACKNOWLEDGEMENTS}

The authors would like to thank Dayasari Residential Colleges at the University of Malaya campus for their permission to carry out the Post Occupancy Evaluation. This work was conducted as part of the fulfilment of the requirements for the degree of Doctor of Philosophy and financially supported by the Institut Pengurusan dan Pemantauan Penyelidikan (IPPP), University of Malaya under PPP Grant (PV063/2011A).

\section{REFERENCES}

Ahmad, S.A. (2008). Kuala Lumpur: A hot humid climate. In R. Hyde (Ed) Bioclimatic Housing: Innovative Designs for Warm Climates, (269-293). UK: Earthscan.

Al-Obaidi, M.A.A.H. \& Woods, P. (2006). Investigations on effect of the orientation on thermal comfort in terraced housing in Malaysia. International Journal of Low Carbon Technologies, 1, 168-176.

Amole, D. (2009). Residential satisfaction in students' housing. Journal of Environmental Psychology, 29, 76-85.

Bondars, E. (2013). Implementing bioclimatic design in sustainable architectural practice. Architeture and Urban Planning, 7, 84-86.

Hadjri, K. \& Crozier, C. (2009). Post-occupancy evaluation: Purpose, benefits and barriers. Facilities, 27, 21-33.

Hyde, R. (2000). Climate responsive design: A study of buildings in moderate and hot humid climates. New York: Taylor \& Francis.

Hyde, R. (2008). Bioclimatic housing: Innovative designs for warm climates. UK: Earthscan.

Jamaludin, A.A. (2014). Performance of bioclimatic design strategies at residential buildings in University of Malaya. Unpublished Ph.D. Thesis. Kuala Lumpur, Malaysia: University of Malaya.

Jamaludin, A.A., Inangda, N., Ariffin, A.R.M. \& Hussein, H. (2012). Energy performance: A comparison of four different multi-residential building designs and forms in the equatorial region. International Journal of Renewable Energy Resources, 2, 13-22.

Jamaludin, A.A., Inangda, N., Ariffin, A.R.M. \& Hussein, H. (2011). Energy performance of three residential college buildings in University of Malaya campus, Kuala Lumpur. Journal of Design and Built Environment, 9, 59-73.

Jamaludin, A.A., Keumala, N., Ariffin, A.R.M. \& Hussein, H. (2014a). Satisfaction and perception of residents towards bioclimatic design strategies: Residential college buildings. Indoor and Built Environment, 23, 933-945.

Jamaludin, A.A., Keumala, N., Ariffin, A.R.M. \& Hussein, H. (2014b). Landscape and sustainability: Three residential college buildings in the tropics. Open House International, 39, 92-106.

Jamaludin, A.A., Mahmood, N.Z., Keumala, N.I., Ariffin, A.R.M. \& Hussein, H. (2013). Energy audit and prospective energy conservation: Studies at residential college buildings in a tropical region. Facilities, 31, 158-172.

Jughans, L. (2008). Design, elements and strategies: Daylighting. In R. Hyde (Ed) Bioclimatic Housing: Innovative Designs for Warm Climates, (297- ). UK: Earthscan.

Karjalainen, S. (2007). Gender differences in thermal comfort and use of thermostats in everyday thermal environment. Building and Environment, 42, 1594-1603.

Khalil, N. \& Nawawi, A.H. (2008). Performance analysis of government and public buildings via post occupancy evaluation. Asian Social Science, 4, 103-112. 
Adi Ainurzaman Jamaludin, Hazreena Hussein, Nila Keumala, Ati Rosemary Mohd Ariffin

Preference of Student Residents Towards Sustainable - Energy Efficient Building with Bioclimatic Design Strategies

Khalil, N. \& Husin, H.N. (2009). Post occupancy towards indoor environment improvement in Malaysia's office buildings. Journal of Sustainable Development, 2, 186-191.

Khalil, N., Husin, H.N., Nawawi, A.H. \& Hashim, A.E. (2008). Post occupancy evaluation for performance evaluation of building facilities in higher education buildings. Proceedings of the $9^{\text {th }}$ International Conference SENVAR \& $2^{\text {nd }}$ ISESEE 2008, 1-3 December 2008, University Teknologi MARA, Malaysia.

Kubota, T., Chyee, D.T.H. \& Ahmad, S. (2009). The effects of night ventilation technique on indoor thermal environment for residential buildings in hot-humid climate of Malaysia. Energy and Buildings, 41, 829-839.

Li, D.H., Yang, L. \& Lam, J.C. (2013). Zero energy buildings and sustainable development implications - A review. Energy, 54, 1-10.

Malaysian Meteorological Department. (2015). Monthly Weather Bulletin. http://www.met.gov.my/index.php?option=com_content\&task=view\&id=846\&Ite mid=1586 (retrieved date: January 16, 2015).

Meir, I.A., Garb, Y., Jiao, D. \& Cicelsky, A. (2009). Post-occupancy evaluation: An inevitable step toward sustainability. Advances in Building Energy Research, 3, 189-219.

Monteiro, L.M. \& Alucci, M.P. (2009). The impact of vegetation on outdoor thermal comfort in urban spaces. Proceedings of the $7^{\text {th }}$ International Conference on Urban Climate, 29 June - 3 July 2009, Yokohama, Japan.

Olgyay, V. (1963). Design with climate: Bioclimatic approach to architectural regionalism. Princeton, NJ: Princeton University Press.

Parsons, K.C. (2002). The effects of gender, acclimation state, the opportunity to adjust clothing and physical disability on requirements for thermal comfort. Energy and Buildings, 34, 593-599.

Preiser, W.F.E. (1995). Post-occupancy evaluation: How to make buildings work better. Facilities, 13, 19-28.

Riley, M., Kokkarinen, N. \& Pitt, M. (2010). Assessing post occupancy evaluation in higher education facilities. Journal of Facilities Management, 8, 202-213.

Shahidan, M.F., Shariff, M.K.M., Jones, P., Salleh, E. \& Abdullah, A.M. (2010). A comparison of Mesua ferreaL. and Hura crepitansL. for shade creation and radiation modification in improving thermal comfort. Landscape and Urban Planning, 97, 168-181.

Singh, M.K., Mahapatra, S. \& Atreya. S.K. (2011). Adaptive thermal comfort model for different climatic zones of North-East India. Applied Energy, 88, 2420-2428.

Tiyok, P. (2009). Towards Indonesia's Sustainable future: Green building council Indonesia. FuturArc, 14, 116-119.

University of Malaya. (2015). Campus Map. https://www.um.edu.my/about-um/contactus/campus-map (retrieved date: February 2, 2016)

White, E.V. \& Gatersleben, B. (2011). Greenery on residential buildings: Does it affect preferences and perceptions of beauty? Journal of Environmental Psychology, 31, 89-98.

Yamane, T. (1967). Statistic, an Introductory Analysis. New York: Harper \& Row.

Yeang, K. (2008). Ecodesign: A Manual for Ecological Design. London, UK: John Wiley \& Son Ltd.

Zakaria, A. \& Hamzah, S. (2007, August 14). Sektor awam perlu bantu. Berita Harian, p. 3. 